\title{
Evaluation of an AutoAnalyzer method for quantitating anti-A and anti-B haemagglutinins in factor VIII preparations
}

\author{
PJ BOWELL, * S ABDALLA,* TJ SNAPE, $†$ AND HH GUNSON* \\ From the *Regional Transfusion Centre, Oxford, and the †Plasma Fractionation Laboratory, Oxford, UK
}

SUMMARY The continuous flow principle employed in the Technicon ${ }^{\circledR}$ AutoAnalyzer has been adapted for the assay of anti-A and anti-B. The method has an acceptable degree of reproducibility and has been used, principally, for the quantitation of anti-A and anti-B in factor VIII concentrates of intermediate activity. It is, however, a method that can be applied to the assay of these antibodies in serum samples.

Attention has been drawn to instances of haemolysis after intensive therapy of group $A, B$, and $A B$ haemophiliacs with factor VIII preparations containing variable quantities of anti-A and anti-B. ${ }^{1-4}$ In order to assess the clinical significance of anti-A and anti-B levels in various factor VIII preparations it was suggested that assay of these antibodies should be carried out on batches produced at Blood Products Laboratory, Elstree and the Plasma Fractionation Laboratory, Oxford (Maycock, personal communication). Estimations of anti-A and anti-B are usually performed by manual titration, a technique liable to exhibit poor reproducibility between operators. Since the AutoAnalyzer has proved successful for the assay of anti-Rh (D) and found to be reliable in the estimation of the strength of the $\mathrm{ABH}$ antigens $\mathrm{s}^{5-7}$ it was decided to adapt the continuous flow principle to the assay of anti-A and anti-B. An assessment of the method and its use for the quantitation of anti-A and anti-B in factor VIII preparations of intermediate specific activity is described in this paper.

\section{Material and methods}

A P PARATUS

The AutoAnalyzer manifold was based on that described by Rosenfield and Haber, ${ }^{8}$ with modifications incorporated by Gunson et al. ${ }^{9}$ In addition, a horizontal coil giving a 10-minute delay was added immediately before the entry of the rouleaux dispersal agent. This coil and, as recommended by Gunson et al., ${ }^{10}$ the settling loop and decants were

Received for publication 28 February 1980 maintained at constant temperature $\left(15^{\circ} \mathrm{C}\right)$. An 8 $\mathrm{mm}$ flow cell was used in the colorimeter in association with a $410 \mathrm{~mm}$ interference filter. The sampling rate was 30 per hour and the sample wash ratio was $2: 1$

\section{REAGENTS}

Test red cells comprised pools of six $A_{1}$ or B samples, collected into ACD or sodium sequestrene, less than 5 days old. Each pool was bromelised before use, as described by Gunson et al., ${ }^{11}$ and was prepared as a $5 \%$ suspension as follows:

$4.4 \mathrm{ml}$ red cells, $12.0 \mathrm{ml} \mathrm{AB}$ serum, $18.8 \mathrm{ml} 30 \%$ bovine serum albumin (BSA), and $36.4 \mathrm{ml} 0.5 \%$ BSA in $0.15 \mathrm{M} \mathrm{NaCl}$ containing $0.02 \%$ Tween 20 . AB serum samples and BSA preparations were screened using the AutoAnalyzer before use in order to eliminate those containing haemagglutinins against A or B red cells, and additionally BSA was examined for the presence of inhibitors. ${ }^{12}$ Polyvinylpyrollidone (PVP) K90 was used as the rouleaux-inducing reagent at concentrations between $1.8 \%$ and $2.0 \%$, these being optimum for the production of rouleaux while resulting in an acceptable base-line.

The standard used was obtained by collecting 6 to 8 $\mathrm{ml}$ serum from 490 samples unselected for $\mathrm{ABO}$ group. After 36 hours at $4^{\circ} \mathrm{C}$, during which screening for atypical red cell alloantibodies and hepatitis B surface antigen was carried out, the 457 acceptable serum samples were pooled, centrifuged, and dispensed as aliquots into 916 neutral glass vials. Check weighing every 50th vial showed the mean weight of serum to be $1.0038 \mathrm{~g} \pm 0.0061 \mathrm{~g}$ (coefficient of variation, $0.06 \%$ ). After lyophilisation the material was stored at $-30^{\circ} \mathrm{C}$. The standard was prepared for use by 
placing the entire redissolved contents of five vials of the lyophilised material into a volumetric flask and adding diluent $(0.5 \% \mathrm{BSA}$ in $0.15 \mathrm{M} \mathrm{NaCl})$ to exactly $50 \mathrm{ml}$. Approximately $2 \mathrm{ml}$ aliquots were frozen at $-40^{\circ} \mathrm{C}$ and stored for up to three months before use. During this period it was shown that there was no significant decay of antibody activity. An aliquot was thawed on the day of use; residual material was discarded. Each vial was designated to contain 100 units of anti-A and 100 units of anti-B. Thus the concentration of the material diluted for use was 10 units per $\mathrm{ml}$.

A second standard was used in one experiment. This comprised a pool of $\mathbf{4 0}$ ampoules of factor VIII intermediate concentrate prepared by the Plasma Fractionation Laboratory, Oxford. The freeze-dried pool was prepared for use as described for the serum standard above. The anti-A concentration of the factor VIII standard, determined as the mean of 28 independent assays against the serum standard over a 10-month period, was 146 units per ml.

\section{METHOD OF ASSAY}

Dilutions of the serum standard, bromelised test red cells, PVP, and air were pumped into the manifold. The agglutination reaction was allowed to take place at $37^{\circ} \mathrm{C}$ for 18 minutes followed by 10 minutes at $15^{\circ} \mathrm{C}$. Rouleaux were dispersed by the addition of $0.5 \% \mathrm{BSA}$ in $0.15 \mathrm{M} \mathrm{NaCl}$. After sedimentation, the agglutinates were decanted, and the residual haemoglobin concentration after lysis of the unagglutinated red cells was measured colorimetrically. The dilutions of the standard were chosen so that there was a linear relationship between the antibody concentration and the response measured as $\triangle O D$, ie, OD of the base-line minus that of the peak height. Figure 1 illustrates a typical standard curve for antiA assay which is sigmoid in shape, giving a linear relationship between 0.2 and 0.5 unit anti-A. This corresponded to a range of 10 to $55 \%$ agglutination when compared with the OD response of the undiluted standard. Values for assay of anti-B were comparable. Test antisera were diluted so that the response $(\triangle \mathrm{OD})$ fell within this range, and the antibody concentration was determined by reference to the standard graph. Each assay comprised a mean of two independent assays and was accepted as valid only when each assay value fell within $\pm 20 \%$ of this mean.

\section{FACTORS AFFECTING THE ASSAY}

\section{Concentration of test red cell suspension}

Agglutination of $A_{1}$ and $B$ red cells with the corresponding isoagglutinin is not as sensitive in the AutoAnalyzer as the reaction between $\mathrm{Rh}(\mathrm{D})$ positive

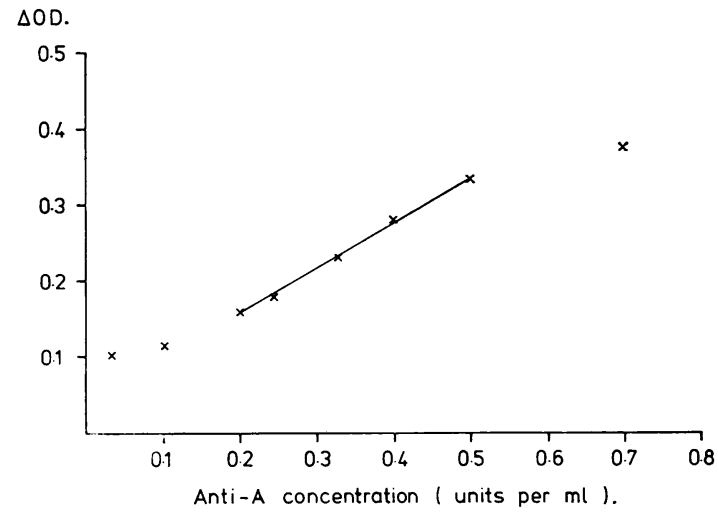

Fig. 1 Dose response against $A_{1}$ test red cells, measured as $\triangle O D$, of varying concentrations of anti- $A$ in the serum standard.

cells and anti-D. It was found that, by using a $5 \%$ test red cell suspension combined with the use of an 8 $\mathrm{mm}$ flow cell and a $410 \mathrm{~nm}$ filter in place of the $20 \%$ red cell suspension, and a $15 \mathrm{~mm}$ flow cell and 550 nm filter normally recommended for anti-D, that a threefold increase in sensitivity could be achieved (Table 1).

Table 1 Comparison of OD using $5 \%$ and $20 \%$ group $A_{1}$ test red cell suspensions against dilutions of the standard

\begin{tabular}{lll}
\hline Units of anti- $A$ & \multicolumn{2}{l}{$O D$ with $A_{1}$ test cells } \\
\cline { 2 - 3 } & $20 \% / 550$ nm filter & $5 \% / 410$ nm filter \\
\hline 0.10 & 0.01 & 0.08 \\
0.11 & 0.02 & 0.10 \\
0.13 & 0.02 & 0.11 \\
0.14 & 0.03 & 0.13 \\
0.17 & 0.03 & 0.15 \\
0.20 & 0.04 & 0.20 \\
0.25 & 0.05 & 0.23 \\
0.33 & 0.06 & 0.30 \\
0.40 & 0.06 & 0.35 \\
0.50 & 0.08 & 0.37 \\
0.67 & 0.12 & 0.45 \\
1.00 & 0.18 & 0.52 \\
2.00 & 0.21 & 0.59 \\
\hline
\end{tabular}

Use of AB serum in the test red cell suspending medium Since the group specific substances in $A B$ serum may effect a partial neutralisation of anti-A and anti-B, several alternatives were investigated. Ficoll $(2 \cdot 5$ to $9.0 \%$ ), plasma protein fraction, and BSA were unsatisfactory due either to the failure to protect the red cells against haemolysis or an unacceptable reduction in sensitivity. Serum pools from $A_{2} B$ nonsecretor donors were found to contain alloantibodies when used in the AutoAnalyzer, resulting in an unacceptably high base line. In order to investigate the extent of neutralisation, bromelised group A test 
red cell suspensions were prepared as above, but using a pool of AB serum from donors unselected for secretor status, serum from a group $A_{1}$ secretor donor, and serum from a group $A_{2}$ non-secretor donor respectively. The three red cell suspensions were allowed to react with dilutions of the serum standard. Figure 2 illustrates the responses obtained, and it can be seen that the test red cells suspended in the serum from the $A_{1}$ secretor donor gave decreased sensitivity.

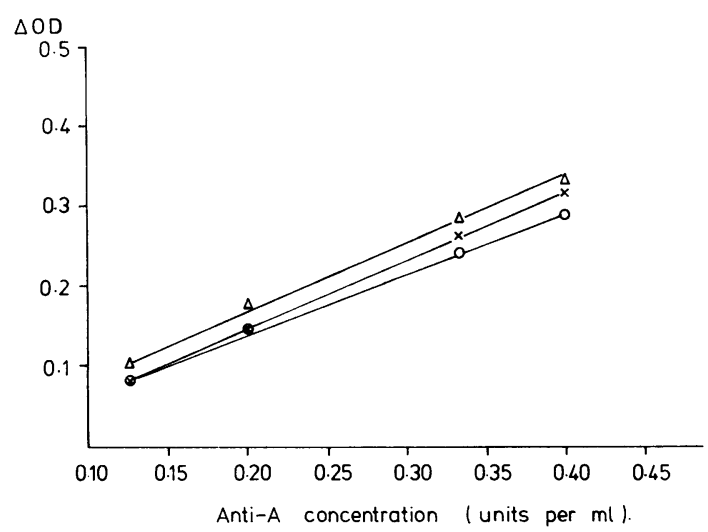

Fig. 2 Effect of use of serum from $A_{1}$ secretor $(O)$, $A_{2}$ non-secretor $(X)$, and pooled $A B$ serum $(\triangle)$ in the test red cell suspension on the standard graph of the serum standard $\mathrm{v} A_{1}$ test red cells.

A further experiment revealed that the neutralisation predominantly affected the IgM component of anti-A (and anti-B). The pooled factor VIII standard and the serum standard, however, behaved in a manner similar to a serum containing only IgG anti-A (and anti-B). On this basis, therefore, it was decided to retain $A B$ serum in the red cell suspending medium.

\section{Use of serum standard}

It is usual practice to employ the same base material in the standard as that of the test in order that the reactions of the two are comparable. The use of a pooled serum standard, however, has the advantage that a single standard can be used for the assay of anti-A and anti-B in serum and factor VIII preparations and possibly other preparations, for example, factor IX. In order to investigate the feasibility of this proposal, the anti-A levels in 33 factor VIII preparations were determined using both the serum and factor VIII standards. Figure 3 illustrates the comparison of the assay values against the two standards. Statistical analysis by the paired $t$ test and by Wilcoxon's signed rank test (distribution-free) confirmed that significant differences did not exist

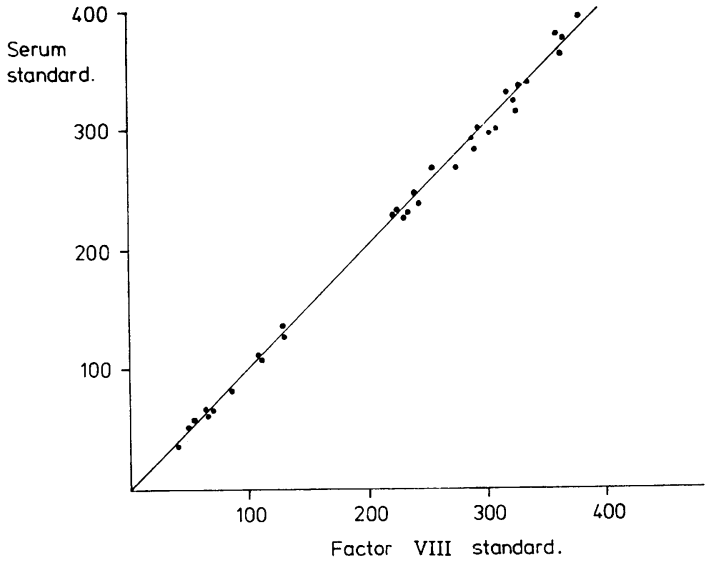

Fig. 3 Comparison of anti-A concentration in factor VIII concentrates using serum and factor VIII standards.

between paired observations against the two standards, and the serum standard has been employed routinely.

\section{REPRODUCIBILITY STUDIES}

This reproducibility of the assay under working conditions was tested by performing 10 to 14 repeated assays of samples on the same day and on different days. The results are shown in Table 2 .

Table 2 Schedule of assays used in determination of reproducibility of anti-A/anti-B assay and mean antibody concentrations in the sets of assays

\begin{tabular}{|c|c|c|c|}
\hline \multicolumn{2}{|c|}{ Antibody } & $\begin{array}{l}\text { No. independent assays } \\
\text { in each set }\end{array}$ & $\begin{array}{l}\text { Mean antibody } \\
\text { concentrotion } \\
(U / m \text { l in sets of assays) }\end{array}$ \\
\hline Anti-A & $\begin{array}{l}\text { Within day } \\
\text { Between days }\end{array}$ & $\begin{array}{l}11 \\
11 \\
13 \\
14 \\
12\end{array}$ & $\begin{array}{r}54 \\
244 \\
58 \\
53 \\
336\end{array}$ \\
\hline Anti-B & $\begin{array}{l}\text { Within day } \\
\text { Between days }\end{array}$ & $\begin{array}{l}10 \\
11 \\
10 \\
10\end{array}$ & $\begin{array}{r}71 \\
326 \\
37 \\
385\end{array}$ \\
\hline
\end{tabular}

Since the estimated variance for each set of observations was proportional to the mean for that set; and since the samples studied varied greatly in anti-A/ anti-B content (Table 1), the analysis was performed on the logs of estimate rather than on the estimates themselves. The standard deviations quoted below are the log standard deviation for each type expressed in anti-log form as a percentage. The findings may be summarised as follows:

Anti-A, within day standard deviation $\pm 5.4 \%$ between day standard deviation $\pm 5.0 \%$ 
Anti-B, within day standard deviation $\pm 5.4 \%$ between day standard deviation $\pm 3.4 \%$

\section{Considerations affecting assay validity}

The method of calculating assay results assumes that the assay is a 'dilution assay', that is, that a test preparation behaves simply as a dilution of the standard preparation. In an assay in which response (in this case $\triangle O D$ ) is plotted against dose (in this case inverse of dilution), two preparations with different starting levels should result in a pair of straight lines of different slope intersecting at zero concentration. Rigorous testing of the extent to which the assays performed satisfied the criteria for such a slope-ratio assay was impractical. Assay validity was tested in an empirical fashion, however, by the assay on 24 occasions of a factor VIII preparation at five dilutions within the working range of the assay. Departure from validity would be expected to result in a different anti-A estimation being returned at each dilution. In fact, differences between values returned at the five different dilutions were not significant at the $5 \%$ level and only just significant at the $10 \%$ level. The highest and lowest mean values for the dilutions tested were $101.4 \%$ and $98 \%$ of the overall mean respectively.

\section{Comparison of anti- $A$ and ant $i-B$ assay with titre}

Estimates of anti-A and anti-B concentration and antiglobulin titres were compared for $\mathbf{4 4}$ factor VIII preparations. It can be seen from Table 3 that, while there is a rise in mean antibody concentration with a rise in titre, there is a considerable spread of antibody concentrations for a given titre, particularly in samples with a titre greater than 1 in 4 . These findings are similar to those for anti-Rh(D) ${ }^{13}$ and probably reflect the greater tendency for manipulative errors to be more pronounced as the titre increases.

\section{Comment}

The AutoAnalyzer has been successfully adapted for the assay of anti-A and anti-B. Reproducibility of the assay is satisfactory but can be achieved only by meticulous attention to the detail of the method, particularly with respect to the preparation of dilutions of both test material and standard. It will be noted that final assay value reported is the mean of two independent assays provided that neither value differs by more than $\pm 20 \%$ of the mean. If this criterion was not fulfilled the assay was repeated. This procedure was based on the experience of the authors with anti-D quantitation using the AutoAnalyzer following the observations by Gunson et al. ${ }^{14}$ It has proved valuable in preventing distortion of the final value due to a single aberrant result and is to be recommended.

One limitation of the method described above is the potential underestimation of the concentrates of anti-A and/or anti-B in preparations containing principally IgM antibody. In our hands, the search for an acceptable alternative to AB serum in the test red cell suspending medium was not successful. However, the serum and factor VIII standards behaved in a manner similar to a serum containing only IgG anti-A. Factor VIII concentrates are prepared from large pools of plasma and contain principally IgG antibody (unpublished observations), and the use of $\mathrm{AB}$ serum in the test red cell suspending medium is, therefore, unlikely to lead to gross underestimation of the antibody concentration. The method reported was devised for the assay of anti-A and anti-B in factor VIII preparations but it can be applied successfully to the assay of those antibodies in serum samples. Results of the investigations into both these aspects will be the subject of a further communication.

\section{References}

${ }^{1}$ Ashenhurst JB, Langehennig PL, Seeler RA, Telfer MC. Hemolytic anaemia due to anti-B in antihemophiliac factor concentrates. $J$ Pediatr 1976;88:257-8.

2 Rosati LA, Barnes B, Oberman HA, Penner JA. Hemolytic anemia due to anti-A in concentrates antihemophilic factor preparations. Transfusion 1970;10:139-41.

${ }^{3}$ Seeler RA. Hemolysis due to anti-A and anti-B in Factor VIII preparations. Arch Intern Med 1972;130:101-3.

4 Tamagnini GP, Dormandy KM, Ellis D, Maycock W d'A. Factor VIII concentrate in haemophilia. Lancet 1975;2: 188.

5 Hunt HW, Morton NE. Quantitative hemagglutination in the ABO system. Am J Hum Genet 1969;21:84-98.

- Monnet A, Cabadi Y. Automation of quantitative methods in immunohaematology. Application to ABO

Table 3 Comparison of antiglobulin titres of anti-A and anti-B with haemagglutination assay

\begin{tabular}{|c|c|c|c|c|c|c|c|c|}
\hline & & \multicolumn{7}{|c|}{ Antiglobulin titre } \\
\hline & & 1 & 2 & 4 & 8 & 16 & 32 & 64 \\
\hline $\begin{array}{l}\text { Anti-A assay } \\
\text { Anti-B assay }\end{array}$ & $\begin{array}{l}\text { Mean } \\
\text { (Range) } \\
\text { Mean } \\
\text { (Range) }\end{array}$ & $\begin{array}{l}17 \cdot 5 \\
(14-21)\end{array}$ & $\begin{array}{c}37 \cdot 0 \\
(33-43)\end{array}$ & $\begin{array}{c}46 \cdot 7 \\
(41-51) \\
48 \cdot 2 \\
(43-81)\end{array}$ & $\begin{array}{l}76 \cdot 2 \\
(41-140) \\
128 \\
(58-213)\end{array}$ & $\begin{array}{l}127 \\
(65-205) \\
251 \\
(194-326)\end{array}$ & $\begin{array}{l}316 \\
(125-455) \\
301 \\
(214-411)\end{array}$ & $\begin{array}{l}324 \\
(262-417)\end{array}$ \\
\hline
\end{tabular}


system. Vox Sang 1974;26:238-46.

7 Sturgeon P, McQuiston D. Fully automated system for the quantitation of $\mathrm{A}_{1}, \mathrm{~B}$ and $\mathrm{H}$ substances. Automation in Analytical Chemistry, Technicon Symposium 1966; 122-5.

${ }^{8}$ Rosenfield RE, Haber GB. Detection and measurement of homologous human hemagglutinins. Automation in Analvtical Chemistry, Technicon Symposium 1965; 503-6.

${ }^{9}$ Gunson HH, Phillips PK, Stratton F. Manipulative and inherent errors in anti-D quantitation using the AutoAnalyzer. J Clin Pathol 1972;25:198-205.

${ }^{10}$ Gunson HH, Phillips PK, Stratton F. The effect of ambient temperature on the anti-D assay using the AutoAnalyzer. J Clin Pathol 1974;27:356-8.

11 Gunson HH, Phillips PK, Stratton F. The adverse effect of

$$
\text { 西 }
$$

bromelin in anti-D quantitation using the AutoAnalyzer. $J$ Clin Pathol 1972;25:206-9.

${ }_{12}$ Gunson HH, Phillips PK. An inhibitor to erythrocyte agglutination in bovine albumin preparations. Vox Sang 1975;28:207-17.

${ }^{13}$ Gunson HH, Stratton F, Phillips PK. The anti-Rho(D) responses of immunized volunteers following spaced antigenic stimuli. Br J Haematol 1974;27:171-82.

${ }^{14}$ Gunson HH, Phillips PK, Stratton F. Observations on the reproducibility of the bromelised test cell anti-D assay using the AutoAnalyzer. Vox Sang 1974;26:334-43.

Requests for reprints to: PJ Bowell, Regional Transfusion Centre, John Radcliffe Hospital, Headington, Oxford OX3 9DU, UK. 